thickness at upper stem levels in the vicinity of the point of maximum crown diameter $^{3}$ was still soft and offered little resistance to the sharp point of the gauge.

The most serious mistake in bark gauge measurements was the practice of pushing the gauge through the bark by means of a "whack" with the inner side of the hand. This nearly always resulted in a penetration of the wood.

\title{
Combined Variable Equations and Volume-Basal Area Ratios for Total Cubic Foot Volumes of the Commercial Trees of B.C. ${ }^{1}$ \\ By J. Harry G. Smithi and Robert E. Breadon ${ }^{2}$
}

Numerous studies have shown that volume per tree varies directly with the combined variable, d.b.h. ${ }^{2} \times$ height $\left(D^{2} H\right)$. Spurr's (1952) (1954) combined variable forms of expressing cubic foot volume of trees are well suited to use of a desk calculator in summary of cruise data and in studies of growth and yield. The combined variable equations also can be converted to find ratios of volume to basal area for point sampling.

The standard total-cubic-foot volume tables of the British Columbia Forest Service (Browne 1962) are based on a logarithmic equation. For table 1 these have been converted to show total cubic foot volume (V) in terms of

$$
\mathbf{a}+\mathbf{b} \frac{\mathrm{D}^{2} \mathrm{H}}{100} \text {. }
$$

All two inch d.b.h. and 10 foot total height classes represented by field data (bold face in Browne's tables) were included in analyses of multiple regression equations on the U.B.C. Computing Center I.B.M. 1620. The regression constants and other pertinent data given in Table 1 are more accurate than those of Smith and Ker (1957) which were based on the preliminary B.C. Forest Service tables. The first equation shown for each species or species group represents trees $2-10$ inches in d.b.h. and the second is based on trees 12 inches d.b.h. or larger. The second equation for mature Douglas firs represents $12-30$ and the third is for trees $32-50$ inches in d.b.h.

The correlation between Browne's volumes and those estimated by the equations of Table 1 is impressively high. Not less than 98.4 percent and an average of 99.8 percent of the variation in tabular volume for each class is accounted for by the equations in Table 1 . The maximum standard error of estimate $\left(\mathrm{SE}_{\mathrm{E}}\right)$ in calculating the logarithmic volumes from the combined variable equations describing trees $2-10$ inches in d.b.h. is that of 80 years or older Douglas fir from the Coast which had an $\mathrm{SE}_{\mathrm{E}}$ of 0.65 cubic feet per tree. Of the trees 12 inches and larger in d.b.h. the largest standard error of estimate in comparison of logarithmic and combined variable equa-

\footnotetext{
${ }^{1}$ Research Note No. 45, Univ. of B.C., Faculty of Forestry.

"Respectively, Associate Professor and Director Research Forest, Univ. of B.C., Faculty of Forestry, Vancouver 8, B.C. The assistance of. Dr. A. Kozak and Mr. J. Hejjas in analysis of the data is gratefully acknowledged.
} 
tions was 39 cubic feet for Sitka spruce over 80 years in age. Since this was only about 3 percent of the mean volume, the standard errors of estimate of individual tree volumes by either approach would be quite acceptable.

The equations were tested graphically to determine the intermediate "limit" $\mathrm{D}^{2} \mathrm{H}$

of - at which both equations give similar values. Means of each group 100 and limiting values of $\frac{\mathrm{D}^{2} \mathrm{H}}{100}$ are given in Table 1 .

Because of the small size of "a" good results can be expected even for very small trees. If the mean $\mathrm{D}^{2} \mathrm{H}$ of a sample were known, further refinements could be made by using the differences between the tabulated means and regression constants to interpolate between the equation constants themselves and from them to zero.

The point sampling factors have been found by the method of Meyers (1963) who expressed the ratio of volume (V) to basal area (B) in terms of $\mathrm{D}$ and $\mathrm{H}$ by dividing both " $a$ " and " $b$ " of the combined variable equation by basal area expressed as $0.005454 D^{2}$. These point sampling factors are given in Table 1 for each combined variable equation.

The slowest increase of the V/B ratio with $\mathrm{H}$ was 0.246 for large mature western red cedar. The fastest increase of $\mathrm{V} / \mathrm{B}$ with $\mathrm{H}$ was 0.479 for 2-10 inch balsam. In some cases the constants shown in Table 1 for division by $D$ are so small that they can be ignored. The tabulated limits calculated for the combined variable equations also should be used for choice of the appropriate equations for V/B. As Evert (1964) has shown these formulas can be used in many ways. The tree of average basal area for each species at each point, or all trees of each species tallied in point sampling, might be used to define $\mathbf{H}$.

A good procedure for use of these $\mathrm{V} / \mathrm{B}$ ratios would be:

1. Point sample for species, d.b.h., and enough heights to define a value for the tree of average $D^{2}$.

2. Find basal area per acre by species.

Then for each species:

3. Find the average value of $\mathbf{D}^{2}$ from the trees counted for basal area.

4. Find the height of the tree of average $D^{2}$.

5. Choose the appropriate " $a$ " and " $b$ " values for V/B from Table 1 dividing a by $\mathrm{D}^{2}$ and multiplying $b$ by $\mathrm{H}$.

6. Multiply B by V/B from " 5 " to get volume per acre.

7. Apply reduction factors for degree of utilization and for waste, breakage and defect to find net merchantable volume.

8. Add species volumes to get total volume per acre.

Both the point sampling factors and the combined variable constants can be expressed in tabular form or used directly as equations. They permit remarkably concise and convenient expressions of the total cubic foot volume of the commercial trees of B.C. 
TABLE 1

Combined Variable Equations for Estimation of Total Cubic Foot Volume of British Columbia Trees

\begin{tabular}{|c|c|c|c|c|c|c|c|c|}
\hline \multirow[b]{2}{*}{ Regior } & \multirow[b]{2}{*}{ Species } & \multirow[b]{2}{*}{ Age } & \multirow{2}{*}{$\frac{\mathrm{D}^{2} \mathrm{H}}{100}$} & \multirow[b]{2}{*}{ Limit } & \multicolumn{2}{|c|}{$\begin{array}{c}\text { Volume } \\
\text { Constants }\end{array}$} & \multicolumn{2}{|c|}{$\begin{array}{c}\text { Volume / Basal Area } \\
\text { Constants } 1\end{array}$} \\
\hline & & & & & $a$ & b & $a$ & b \\
\hline \multirow[t]{2}{*}{$\mathrm{C}$} & Douglas fir & $140-$ & 35 & & 0.18 & 0.220 & 33.0 & .403 \\
\hline & & & 706 & 160 & 11.8 & 0.166 & 2160 & .304 \\
\hline \multirow[t]{3}{*}{$\mathrm{C}$} & Douglas fir & $80+$ & 45 & & 0.23 & 0.214 & 42.2 & .392 \\
\hline & & & 651 & 85 & 4.30 & 0.164 & 788 & .301 \\
\hline & & & 3347 & 840 & 6.17 & 0.149 & 1130 & .273 \\
\hline \multirow[t]{2}{*}{ I } & Douglas fir & All & 30 & 140 & 0.02 & 0.211 & 3.67 & .387 \\
\hline & & & 848 & 140 & 9.45 & 0.155 & 1730 & .284 \\
\hline \multirow[t]{2}{*}{$\mathrm{C}$} & W. red cedar & $140-$ & 28 & & 0.31 & 0.234 & 56.8 & .429 \\
\hline & & & 531 & 130 & 8.92 & 0.169 & 1640 & .310 \\
\hline \multirow[t]{2}{*}{$\mathrm{C}$} & W. red cedar & $80+$ & 29 & & 0.44 & 0.234 & 80.7 & .429 \\
\hline & & & 2202 & 280 & 39.7 & 0.134 & 7260 & .246 \\
\hline \multirow[t]{2}{*}{ I } & W. red cedar & All & 27 & 235 & 0.37 & 0.230 & 68.0 & .422 \\
\hline & & & 1704 & 235 & 27.8 & 0.140 & 5100 & .257 \\
\hline \multirow[t]{2}{*}{$\mathrm{C}$} & W. hemlock & $140-$ & 36 & & 0.02 & 0.243 & 3.7 & .446 \\
\hline & & & 483 & 150 & 3.53 & 0.215 & 647 & .394 \\
\hline \multirow[t]{2}{*}{$\mathrm{C}$} & W. hemlock & $80+$ & 37 & 250 & -0.01 & 0.237 & -1.83 & .435 \\
\hline & & & 1842 & 250 & 21.2 & 0.176 & 3890 & .323 \\
\hline \multirow[t]{2}{*}{ I } & W. hemlock & All & 32 & & 0.09 & 0.226 & 16.5 & .414 \\
\hline & & & 894 & 255 & 2.88 & 0.213 & 528 & .391 \\
\hline \multirow[t]{2}{*}{$\mathrm{C}$} & Balsam spp. & All & 38 & & 0.03 & 0.261 & 5.50 & .479 \\
\hline & & & 1356 & 220 & 15.6 & 0.204 & 2860 & .374 \\
\hline \multirow[t]{2}{*}{ I } & Balsam spp. & All & 29 & & 0.18 & 0.235 & 33.0 & .431 \\
\hline & & & 503 & 150 & 6.29 & 0.197 & 1150 & .361 \\
\hline \multirow[t]{2}{*}{$\mathrm{C}$} & Sitka spruce & $140-$ & 37 & & 0.23 & 0.233 & 42.2 & .427 \\
\hline & & & 932 & 180 & 9.67 & 0.189 & 1770 & .347 \\
\hline & Sitka spruce & $80+$ & 43 & 430 & 0.20 & 0.237 & 36.7 & .435 \\
\hline & & & 4732 & 430 & 58.0 & 0.162 & 10600 & .297 \\
\hline \multirow[t]{2}{*}{ I } & Spruce spp. & All & 32 & on & 0.16 & 0.233 & 29.3 & .427 \\
\hline & & & 870 & 90 & 9.06 & 0.189 & 1660 & .347 \\
\hline \multirow[t]{2}{*}{$\mathrm{C}$} & Yellow cedar & All & 30 & 60 & 0.29 & 0.247 & 53.2 & .453 \\
\hline & & & 677 & 60 & 13.6 & 0.173 & 2490 & .317 \\
\hline \multirow[t]{2}{*}{$\mathrm{C}$} & I White pine & All & 35 & 200 & 0.26 & 0.236 & 47.7 & .433 \\
\hline & & & 837 & 200 & 10.5 & 0.194 & 1930 & .356 \\
\hline $\mathrm{C}$ & I Lodgepole pine & All & 34 & 75 & 0.07 & 0.2511 & 12.8 & .460 \\
\hline & & & 270 & 15 & 2.54 & 0.224 & 466 & .411 \\
\hline $\mathrm{C}$ & I Yellow pine & All & 29 & 40) & -0.08 & 0.220 & -14.7 & .403 \\
\hline & & & 713 & 40 & 1.43 & 0.205 & 262 & .376 \\
\hline I & Larch & All & 38 & 215 & 0.16 & 0.203 & 29.3 & .372 \\
\hline & & & 963 & & 10.2 & 0.164 & 1870 & .301 \\
\hline $\mathrm{C}$, & I Black cottonwood & All & 35 & & 0.05 & 0.209 & 9.17 & .383 \\
\hline & & & 1000 & 210 & 8.32 & 0.173 & 1530 & .317 \\
\hline
\end{tabular}


JUNE, 1964

\begin{tabular}{|c|c|c|c|c|c|c|c|}
\hline \multirow[t]{2}{*}{ C Alder } & All & 35 & 60 & 0.02 & 0.246 & 3.67 & .451 \\
\hline & & 214 & & 1.85 & 0.228 & 367 & .418 \\
\hline \multirow[t]{2}{*}{ C Maple } & All & 36 & 65 & 0.02 & 0.221 & 3.67 & .405 \\
\hline & & 300 & & 1.13 & 0.204 & 207 & .374 \\
\hline \multirow[t]{2}{*}{ C, I Вirch } & All & 31 & 50 & 0.05 & 0.225 & 9.17 & .413 \\
\hline & & 160 & & 0.67 & 0.215 & 123 & .394 \\
\hline \multirow[t]{2}{*}{ C, I Aspen } & All & 30 & 50 & 0.05 & 0.228 & 9.17 & .418 \\
\hline & & 219 & & 1.10 & 0.218 & 202 & .400 \\
\hline
\end{tabular}

2 " $\mathrm{a}$ " is a constant to be divided by average $\mathrm{D}^{2}$; " $\mathrm{b}$ " is to be multiplied by $\mathrm{H}$, e.g. $\mathrm{D}$ of the tree of average squared d.b.h. is $10^{\prime \prime}, \mathrm{H}$ is $100^{\prime}$ in Douglas fir $140-$ then $\frac{\mathrm{V}}{\mathrm{B}}=\frac{33}{10^{2}}$
$+0.403 \times 100=40.63 \mathrm{cu}$. ft. per sq. fr. of basal area.

\section{Literature Cited}

BROWNE, J. E. 1962. Standard cubic-foot volume tables for the commercial trees species of British Columbia, 1962. B.C. Forest Service, Victoria, B.C., 107 p.

EVERT, F. 1964. Comments on "Faster Point Sampling." Jour. For. 62(3): 191.

MYERS, C. A. 1963. Point-sampling factors for Southwestern ponderosa pine. U.S.F.S. Res. Pap. RM-3, 15 p.

SMITH, J. H. G. and KER, J. W. 1957. Timber volume depends on $D^{2} H$. B.C. Lumberman, Sept. 2 pages reprinted.

SPURR, S. H. 1952. Forest inventory. The Ronald Press Co. N.Y., 476 p.

SPURR, S. H. 1954. Simplified computation of volume and growth. Jour. For. 52 (12): 914-922. 